\title{
PHYTATE MINERALIZING BACTERIA AND THEIR PHYTASE ACTIVITY FROM DIFFERENT MATRICES OF TROPICAL FLOODPLAIN WETLANDS
}

\author{
Sanjib Kumar Manna*, Nilanjan Maitra, Chinmay Bandopadhyay, Lucky Nandi ${ }^{1}$, Srikanta Samanta
}

Received 16 April 2021, revised 24 December 2021

\begin{abstract}
Phytic acid constitutes a significant part of total phosphorus (P) load in aquatic sediments, with potential for P release to water. The present study harnessed phytase producing bacteria from different matrices of two floodplain wetlands of West Bengal, India and examined their phytate mineralization activity. Prominent phytate degrading bacterial isolates were identified from 16S rDNA sequences as Bacillus megaterium, Arthrobacter sp., Klebsiella oxytoca, Methylobacterium gregans, and Fictibacillus sp. The bacteria from gut of Cirrhinus mrigala had much higher phytase activity than those from sediment and water. Requirements of $\mathrm{pH}$ for optimum phytase enzyme activity varied widely, in sync with the $\mathrm{pH}$ of respective niche, with highest activity at pH 3-4 for gut bacteria and pH 6-7 for sediment isolates, suggesting their $P$ release potential. Although the sediment bacteria had moderate phytase enzyme activity, presence of large amount of organic matter of plant origin, and congenial physio-chemical environments such as temperature and $\mathrm{pH}$ might make the wetland sediment an important site of phytate degradation towards phosphorus cycling for primary production.
\end{abstract}

Key words: Bacteria, Phytase, Water, Sediment, Fish gut.

\section{INTRODUCTION}

Phytic acid or the myoinositol 1, 2, 3, 4, 5, 6-hexakisdihydrogen phosphate (IP6) is one of the major forms of inositol phosphates (IP) and occurs widely in the environment. Phytate, synthesized widely by plants, accounts for $70-80 \%$ of the total phosphorus present in seed grains (Lott et al. 2000). Human and other monogastric animals including fish consume a large amount of food phytate, which, however, is not digested effectively and is excreted out. The phytate originating from terrestrial runoffs, manures and city sewages containing the undigested nutrient from human and animal excreta have been identified to form a major part of organic phosphorus in aquatic sediments (Suzumura and Kamatani 1995, Turner and Weckström 2009). Plantbased fish feeds, especially those containing oil seed meals or cakes (Bello et al. 2013, Yasothai et al. 2014) add to this quantity in aquatic environments. Macrophytes, abundantly present in majority of the tropical floodplain wetlands also synthesize and contribute phytate to the ecosystem. For example, raw duckweed (Lemna polyrrhiza) leaf has a phytate content of $1.23 \%$ (Bairagi et al. 2002).

In terrestrial soil IP6 accounts for 5.3-83\% of organic P contents (Turner et al. 2002) with a potential to provide phosphorus $(\mathrm{P})$ necessary for plant. In aquatic ecosystems IP6 constitutes from negligible to a significant portion of sediment organic P pool (Chessman et al. 2014, Paraskova et al. 2015). In lakes of tropical China, the level of monoester-P, that includes IP, varied between 21.4 and $82.7 \mathrm{mg} \mathrm{kg}^{-1}$, contributing $1.8-14.3 \%$ to the total sediment $\mathrm{P}$ (Zhang et al. 2009). The concentration of phytic acid in sediments from temporary ponds of the Doijana National Park, Spain, ranged from 9-31 mg kg-1 or higher (Serrano et al. 2000). In Carolina Bay wetlands the IP6 accounts up to $187 \mathrm{mg} \mathrm{kg}^{-1}$ or $46 \%$ of total phosphomonoesters and $11 \%$ of total soil $\mathrm{P}$ (Chessman et al. 2014). Phosphorus is a critical and limiting macronutrient for primary producers, including phytoplanktons. However, unlike terrestrial soil where

ICAR-Central Inland Fisheries Research Institute, Barrackpore, Kolkata-700120, India.

${ }^{1}$ University of Kalyani, Kalyani, Nadia, West Bengal 741235, India.

*Corresponding author. e-mail: sanjibmanna@yahoo.com 
IP may meet $\mathrm{P}$ requirements of plants, bioavailability of phytate-P in aquatic environments is debated with contradictory observations. Due to higher $\mathrm{pH}$-dependent charge density phytate forms stronger complexes with iron hydroxide, other multivalent cations and humic substances that prevent its enzymatic hydrolysis ( $\mathrm{He}$ et al. 2006). In lake sediments the half-life of clustered monoester-P is about 29 years (Reitzel et al. 2007), much higher than other common organic P species, making it a dominant organic P fraction in organic rich wetlands. Due to high degree of recalcitrance and longer environmental persistence, phytate has been argued as a P-specific paleoindicator in aquatic sediments (Turner and Weckström 2009). Phytate-P is generally considered refractory in nature (Reitzel et al. 2007). On the contrary, Zhu et al. (2013) reported bulk recovery of IP6 in the labile $\mathrm{H}_{2} \mathrm{O}$ and $\mathrm{NaHCO}_{3}$ fractions suggesting its amicable nature for hydrolysis. In Tokyo Bay river and estuarine sediments, Suzumura and Kamatani (1995) estimated IP6 at the level of 0.07-0.66 $\mu \mathrm{mol} \mathrm{P} \mathrm{g}{ }^{-1}$ which decreased to 0.01-0.1 $\mu \mathrm{mol}$ $\mathrm{P} \mathrm{g}^{-1}$ in coastal marine zones: this natural mobilization in marine environment matched with hydrolysis of IP in simulated marine sediments. Turner et al. (2006) recorded very low levels of IP6 in treatment wetlands and suggested its rapid degradation.

Phytase enzyme (myo-inositol hexaphosphate phosphohydrolase, E.C.3.1.3.8), responsible for hydrolysis of phytate to lower substituted inositol phosphates and orthophosphate, is synthesized by plants, microorganisms and some animals (Gatlin et al. 2007). Several researchers have worked on soil microbial phytases (Powar and Jagannathan 1982, Greiner et al. 1993, Greiner et al. 1997), and their role in soil productivity improvement by realizing phytate $\mathrm{P}$ is well established (Singh et al. 2014). However, meagre studies have been conducted on phytate degradation in aquatic ecosystems and phytate degradation capability of aquatic microbes, especially from water and sediment. In a different perspective, phytase producing bacteria and yeast such as Rhodococcus sp., Bacillus spp., Candida tropicalis have been isolated from freshwater fish gut with major objective of their potential use in fish feed development (Khan et al. 2011, Khan and Ghosh 2012, Das and Ghosh 2014). The objective of our study was to examine diversity and phytate degradation ability of bacteria from different matrices of freshwater ecosystems with long term goal of enhancing $\mathrm{P}$ availability through microbial phytate degradation.

\section{MATERIALS AND METHODS Study sites}

Water, sediment and fish samples were collected from two freshwater floodplain wetlands, namely, Akaipur $\left(23^{\circ} 04^{\prime} \mathrm{N}, 88^{\circ} 43^{\prime} \mathrm{E}\right)$ and Bhomra $\left(22^{\circ} 59^{\prime} \mathrm{N}, 88^{\circ} 38^{\prime} \mathrm{E}\right)$ wetlands located in rural West Bengal, India. These floodplain wetlands are closed ox-bow lakes with large detritus load that have greatly enriched the sediment with 5470-6040 mg total $\mathrm{P} \mathrm{kg}^{-1}$ sediment. Sediment total

Table 1. Identification of phytate mineralizing bacterial isolates from 16s rDNA sequence information.

\begin{tabular}{|c|c|c|c|c|c|}
\hline Isolate & Isolation Source & Identification & Closest type strain & Identity & $\begin{array}{l}\text { Accession } \\
\text { number }\end{array}$ \\
\hline $\mathrm{APh} 1$ & Akaipur sediment & Bacillus megaterium & $\begin{array}{l}\text { Bacillus megaterium } \\
\text { ATCC } 14581 \mathrm{~T}\end{array}$ & $100 \%$ & ANNS00000000 \\
\hline $\mathrm{APh} 2$ & Akaipur sediment & Bacillus megaterium & $\begin{array}{l}\text { Bacillus megaterium } \\
\text { ATCC } 14581 \mathrm{~T}\end{array}$ & $99 \%$ & KM035406 \\
\hline $\mathrm{BPh} 4 \mathrm{a}$ & Bhomra sediment & Bacillus megaterium & $\begin{array}{l}\text { Bacillus megaterium } \\
\text { ATCC } 14581 \mathrm{~T}\end{array}$ & $99 \%$ & JQ965768 \\
\hline PhIn1 & Fish intestine & Arthrobacter sp. & $\begin{array}{l}\text { Arthrobacter mysorens } \\
\text { DSM 12798T }\end{array}$ & $99 \%$ & JX134618 \\
\hline PhIn2 & Fish intestine & Klebsiella oxytoca & $\begin{array}{l}\text { Klebsiella oxytoca } \\
\text { ATCC } 13182 \mathrm{~T}\end{array}$ & $99 \%$ & JX000001 \\
\hline PhIn3 & Fish intestine & Arthrobacter sp. & $\begin{array}{l}\text { Arthrobacter mysorens } \\
\text { DSM } 12798 \mathrm{~T}\end{array}$ & $99 \%$ & KM035405 \\
\hline PhIn4 & Fish intestine & Methylobacterium gregans & $\begin{array}{l}\text { Methylobacterium gregans } \\
\text { DSM 19564T }\end{array}$ & $99 \%$ & JX134616 \\
\hline PhIn5 & Fish intestine & Fictibacillus sp. & Bacillus sp. Ca7 & $100 \%$ & KM035407 \\
\hline
\end{tabular}


Phytate mineralizing bacteria and their phytase activity from different matrices...

organic carbon (TOC) contents were high, $2.95 \pm 0.09 \%$ and $4.1 \pm 0.2 \%$ in Akaipur and Bhomra wetlands respectively, and macrophyte derived detritus forms an important autochthonus food source to the fish population (Samanta et al.2015). Heavy macrophyte production and washings from surrounding agricultural fields are the major sources of nutrients and organic matter inputs into the wetlands; the wetlands receive meager amounts of domestic wastes and no city sewage. Fish species viz., Labeo rohita, Catla catla, Cirrhinus mrigala, and Hypophthalmichthys molitrix are stocked in moderate density in these wetlands without any supplementary feeding. Top layers ( $0-14 \mathrm{~cm}$ depth) of bottom sediments from different sampling points in wetlands were collected using Ekman dredge; water samples were taken from $0.5 \mathrm{~m}$ depth. From each sampling point one litre of water and $1.5-2 \mathrm{~kg}$ of sediment samples were collected in sterile plastic containers and brought to the laboratory within 2 hours. Cirrhinus mrigala, a detritivore species, was chosen to study the phytase activity of gut bacteria. Live C. mrigala, weighing between 750 and $1200 \mathrm{~g}$, were netted from the wetlands, individually packed in plastic bags and transported to the laboratory under ice cover.

\section{Isolation of phytate mineralizing bacteria (PMB)}

Five grams of each sediment sample and aseptically dissected intestinal contents of individual fish were homogenized in sterile saline $(0.85 \%)$ solution following
Maitra et al. (2015). One hundred microlitres of the $10 \%$ $(\mathrm{w} / \mathrm{v})$ suspension, sample water and their dilutions (10fold dilutions in $0.85 \%$ saline) were plated by spread plate method on to phytate screening medium (also called PMB medium here) containing phytate as the sole source of phosphorus $\left[10 \mathrm{~g} \mathrm{l}^{-1} \mathrm{D}\right.$-glucose, $4 \mathrm{~g} \mathrm{l}^{-1} \mathrm{Na}$ - phytate, $5 \mathrm{~g} \mathrm{l}^{-}$ ${ }^{1} \mathrm{NH}_{4} \mathrm{NO}_{3}, 0.5 \mathrm{~g} \mathrm{l}^{-1} \mathrm{KCl}, 0.5 \mathrm{~g} \mathrm{l}^{-1} \mathrm{MgSO}_{4} .7 \mathrm{H}_{2} \mathrm{O}, 0.01 \mathrm{~g} \mathrm{l}^{-1}$ $\mathrm{FeSO}_{4} \cdot 7 \mathrm{H}_{2} \mathrm{O}, 0.01 \mathrm{~g} \mathrm{l}^{-1} \mathrm{MnSO}_{4} \cdot \mathrm{H}_{2} \mathrm{O}$ and $15 \mathrm{~g} \mathrm{l}^{-1}$ agar, $\mathrm{pH}$ 7.0] (Kerovuo et al. 1998). Following incubation at $30^{\circ} \mathrm{C}$ for 7 days, representative phytate degrading colonies with clear zone of halo around them were picked up, restreaked on PMB agar for presumptive confirmation of phytate degradation, and finally given passages on to Reasoner's $2 \mathrm{~A}\left(\mathrm{R}_{2} \mathrm{~A}\right)$ agar for pure culture isolation.

\section{Quantitative phytate mineralization by bacterial strains}

The phytase activity of the bacterial isolates was measured following Yanke et al. (1998). Briefly, bacteria were grown in phytate screening broth for $72 \mathrm{~h}$ at $30^{\circ} \mathrm{C}$, centrifuged at $10,000 \times \mathrm{g}$ for 10 minutes at $4^{\circ} \mathrm{C}$ and filtered through $0.22 \mu \mathrm{m}$ membrane filters. Cell free culture broth was used for mineralization assay using $0.2 \% \mathrm{w} / \mathrm{v}$ sodium phytate as substrate in $0.1 \mathrm{M} \mathrm{Na}$-acetate buffer ( $\mathrm{pH} \mathrm{5.0)}$ at $39^{\circ} \mathrm{C}$. After 30 minutes of incubation, reaction was terminated with $5 \%(\mathrm{w} / \mathrm{v})$ trichloroacetic acid, and orthophosphate content in the supernatant was measured by the molybdate-blue method (Murphy and

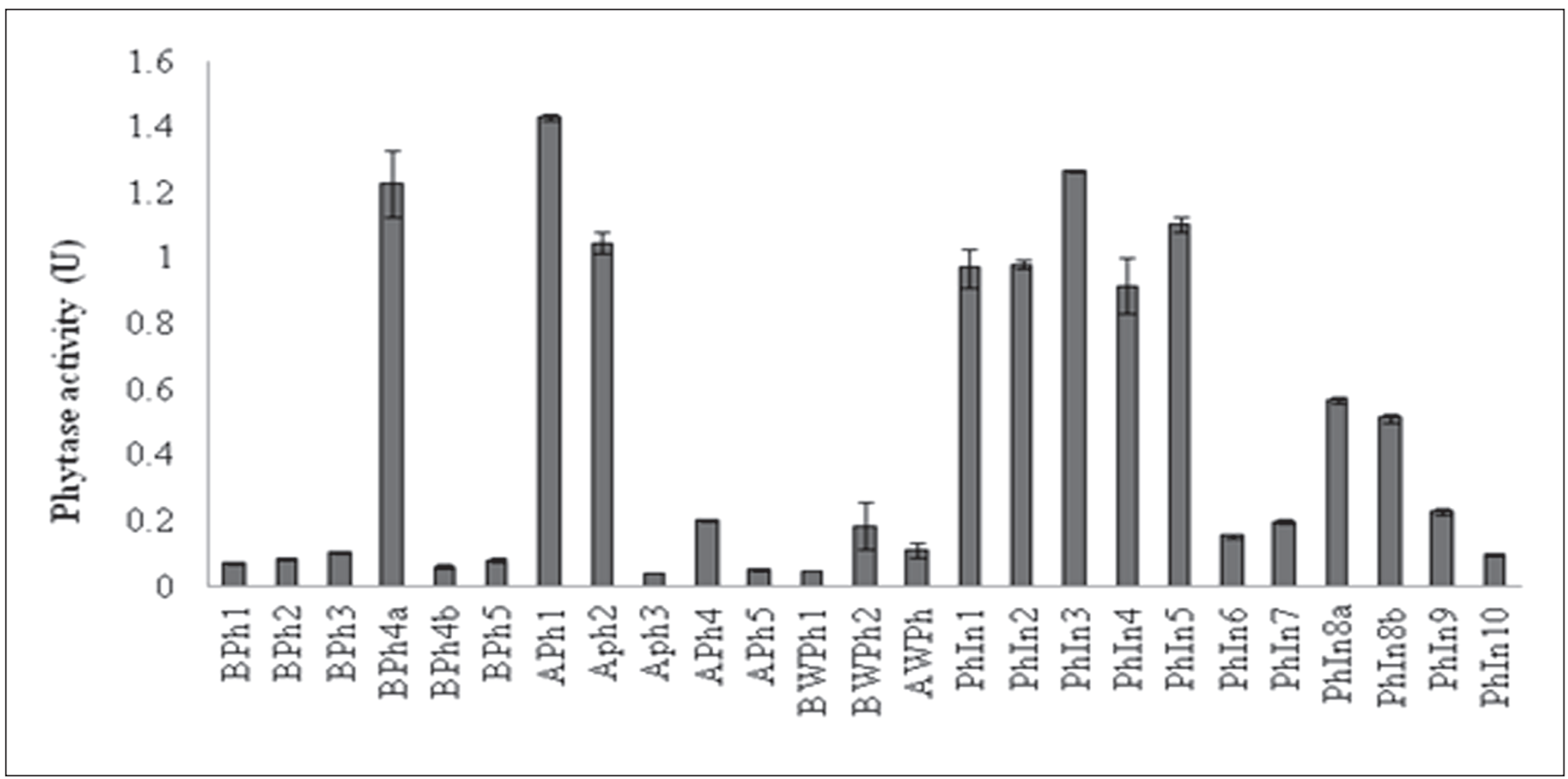

Fig. 1. Phytase activity of the bacterial isolates from wetland ecosystems.

(Strains isolated from Akaipur wetland sediment are named with 'APh', those from Bhomra wetland sediment are named with 'BPh', those from water are named as either “AWPh' or 'BWPh', and those from fish intestine are named with 'PhIn'). 
Riley 1962). Uninoculated medium served as negative control. One phytase unit (U) was defined as $1 \mu \mathrm{g}$ of inorganic phosphorus released per $1 \mathrm{ml}$ of culture filtrate per 1 min.

\section{pH optima of phytase activity}

Since bacteria from different matrices were tested where $\mathrm{pH}$ ranged from around 4 in fish gut to 5.79-7.61 in water and sediment, the optimum $\mathrm{pH}$ for phytase activity of prominent phytate mineralizing strains was determined at $\mathrm{pH}$ 3-7. Briefly, cells were grown for 5 days and cell-free culture broth, prepared by centrifugation and filtration as mentioned above, were tested for phytase activity following Yanke et al. (1998) at $\mathrm{pH}$ 3-7 in 0.1 (M) citrate buffer (pH 3-5), 0.1 (M) acetate buffer (pH 5, 6) and $0.1(\mathrm{M})$ Tris $\mathrm{HCl}$ buffer $(\mathrm{pH}$ $6,7)$ using $0.2 \% \mathrm{w} / \mathrm{v}$ Na-phytate as a substrate. The time and temperature conditions for obtaining $\mathrm{pH}$ optima were kept similar to enzyme assay stated earlier.

\section{Identification of bacteria}

PMB with prominent phytase activity (activity $>0.9$ $\mathrm{U})$ were identified by PCR amplification and sequencing of 16S rDNA as per Maitra et al. (2015). Bacterial Genomic DNA was extracted using GenElute ${ }^{\mathrm{TM}}$ Bacterial genomic DNA Kit (SIGMA- Aldrich) from a fresh pure culture colony grown on nutrient agar, and the gene for $16 \mathrm{~S}$ rRNA was amplified by polymerase chain reaction
(PCR) using bacterial universal primers 8F (5'AGAGTTTGATCCTGGCTCAG-3') and U1492R (5'GGTTACCTTGTTACGACTT-3') following cycle condition of $95^{\circ} \mathrm{C}$ for 1 minute, followed by 30 cycles of $95^{\circ} \mathrm{C}$ for 30 seconds, $57^{\circ} \mathrm{C}$ for 30 seconds and $72^{\circ} \mathrm{C}$ for 2 minutes, and a final extension at $72^{\circ} \mathrm{C}$ for 5 minutes. The PCR reaction mix consisted of $0.2 \mu \mathrm{M}$ of each primer, $10 \mu \mathrm{M}$ of each deoxynucleotides, $1.5 \mathrm{mM}$ of $\mathrm{MgCl} 2,10 \mathrm{X}$ PCR buffer and $0.5 \mathrm{U}$ of Taq DNA polymerase (Invitrogen). The PCR amplicons were separated and visualized in $1 \%$ agarose gel, purified using QIAquick ${ }^{\circledR}$ gel extraction kit (Qiagen) and sequenced by Sanger method. The nucleotide sequences were verified for quality by Sequence Scanner v1.0 software (Applied Biosystems, Inc., US), checked for chimera using Bellerophon (http://comp-bio.anu.edu.au/bellerophon/ bellerophon.pl) and forward and reverses sequences were aligned with codon code aligner (Codon Code Corporation, US) to form contigs which were compared with synonymous sequences using nucleotide BLAST program (Altschul et al. 1997) in GenBank, Ribosomal Database Project (RDP), and Greengenes (http:// greengenes.lbl.gov). The closest match of phylogenetic affiliation was used to assign the sequenced strains to specific taxonomic groups. A phylogenetic tree of the identified bacteria and their type strains, SSU sequences of which were obtained from Taxon passports, was prepared using the Maximum Likelihood method in

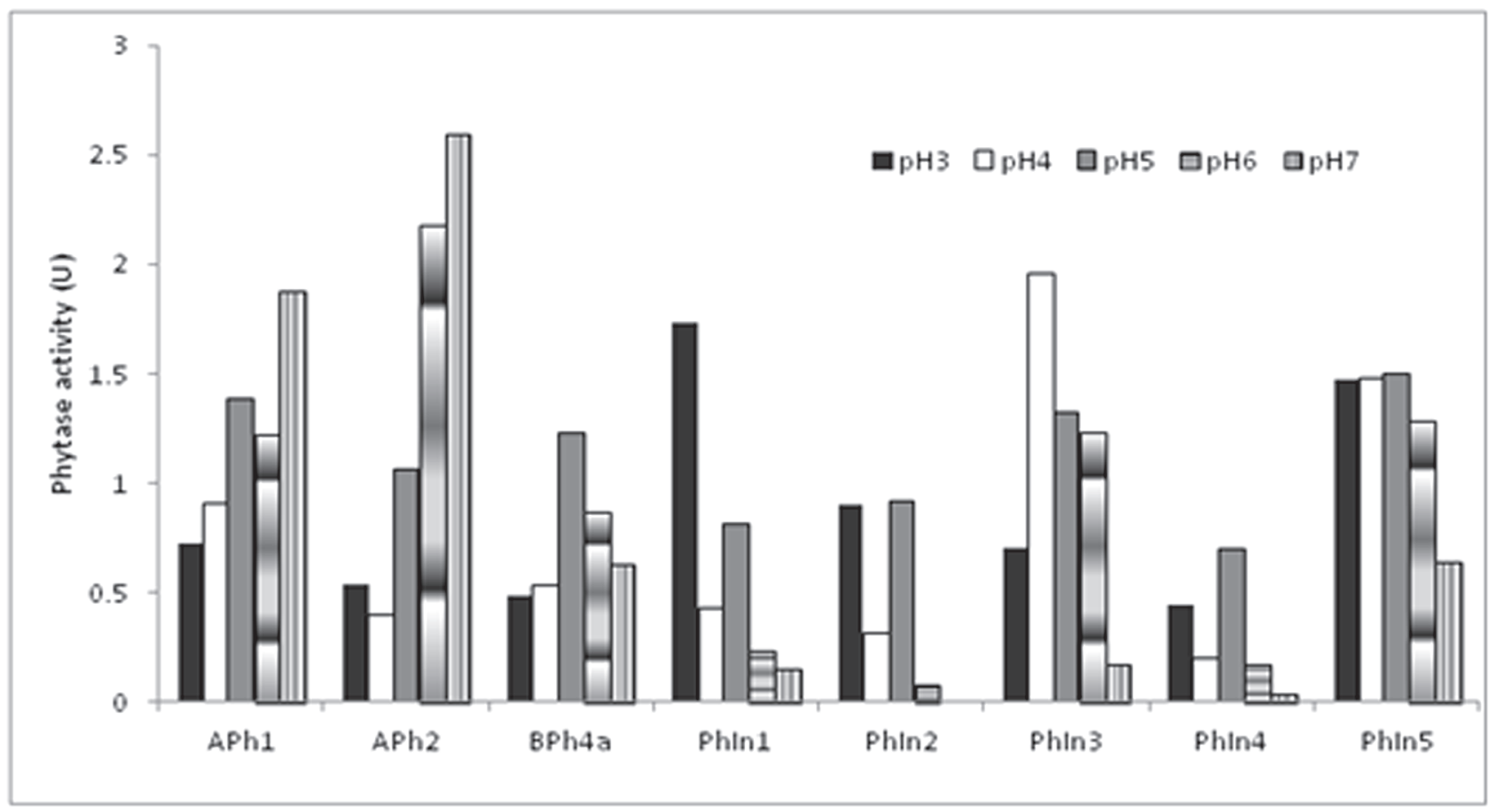

Fig. 2. pH optima of phytase activity of the prominent phytate mineralizing strains. 
Phytate mineralizing bacteria and their phytase activity from different matrices...

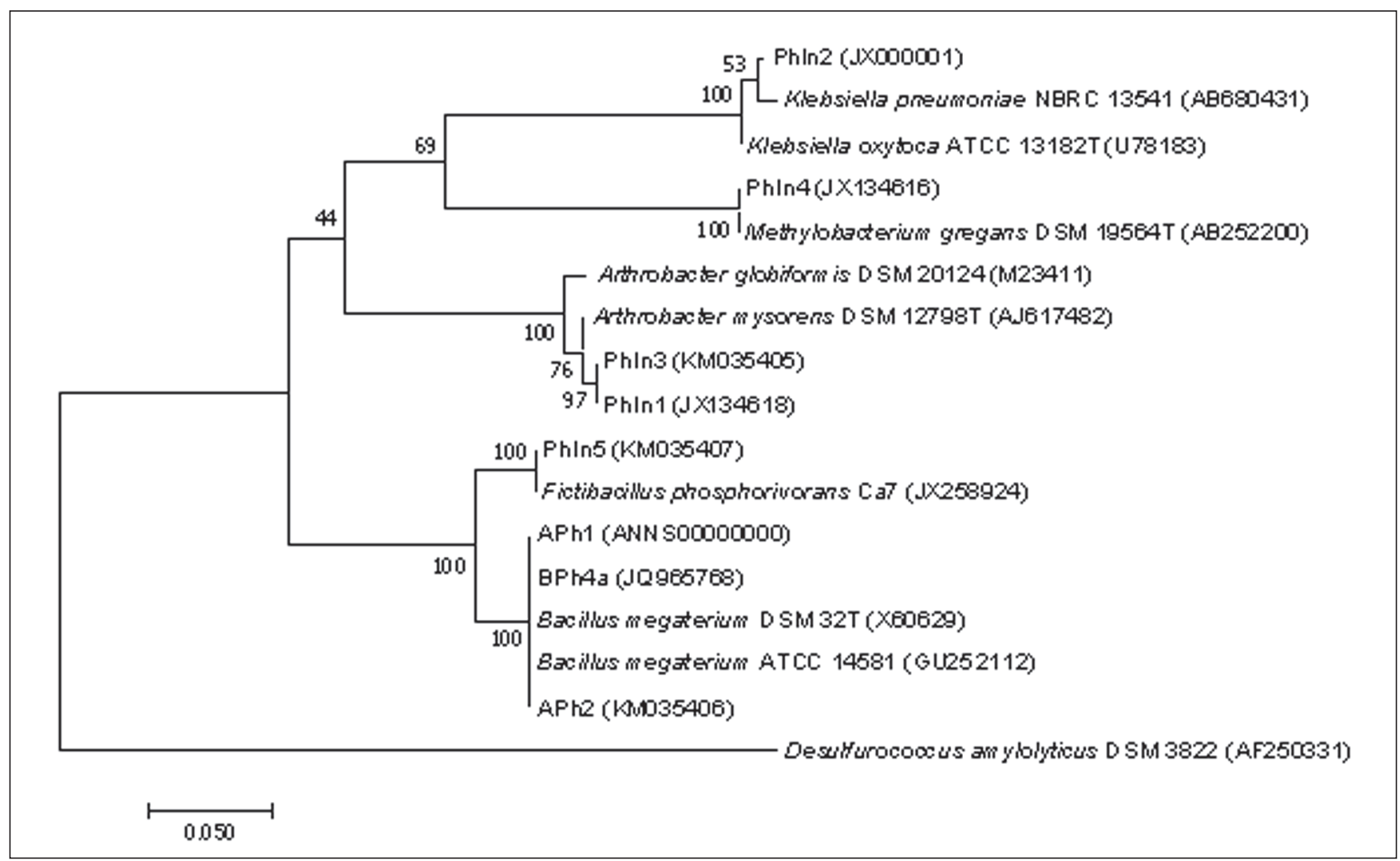

Fig. 3. Phylogenetic tree showing the relationship among PMB and their closest type strains.

[The tree with the highest log likelihood (-2435.15) is shown. Distance matrix was calculated by Tamura-Nei model and Bootstrap analysis was calculated with 1000 replicates bootstrap].

MEGA7 (Kumar et al. 2016), following Tamura-Nei model (Tamura and Nei 1993). The distance matrix was calculated by $\gamma$ distribution method and bootstrap analysis with 1000 replicates was used to test the phylogeny (Felsenstein 1985).

\section{Statistical analysis}

Phytase activities of the bacterial isolates are presented as mean \pm S.E. Difference in phytase activity among the isolates were examined by one sample t-test using SAS Enterprise Guide (4.2).

\section{RESULTS AND DISCUSSION}

\section{Phytate mineralizing bacteria from different freshwater matrices}

Following primary culture, a large number of colonies developed on plates for all the sediment and fish intestinal contents, but a few colonies developed for water samples. Representative colonies with prominent zone of clearing around them were primarily selected for further study. Thus, a total of 25 strains of PMB (11 strains from fish gut, 11 from sediments and 3 from water samples) were isolated from the wetlands.

\section{Quantitative phytate mineralization by bacterial strains}

Phytate mineralization study conducted in acetate buffer, pH 5.0, using Na-phytate as the P source showed that the strains from water, sediment and fish had low to moderate activity, ranging between $0.046 \mathrm{U}$ and $1.427 \mathrm{U}$ (Fig. 1). The enzyme activities of the strains isolated from fish gut $(0.635 \pm 0.129 \mathrm{U})$ were significantly higher than those from sediment $(0.398 \pm 0.164 \mathrm{U})$ and water sources $(0.112 \pm 0.039 \mathrm{U})$. The bacteria isolated from Akaipur wetland sediment had insignificantly higher activity $(0.552 \pm 0.287 \mathrm{U})$ than those from Bhomra sediment $(0.269 \pm 0.191 \mathrm{U})$. Bacillus megaterium from sediments had the highest activity among all the strains.

\section{pH optima of phytate degradation}

Phytase activity of selected strains were tested at different $\mathrm{pH}$ ranging from $\mathrm{pH} 3$ to $\mathrm{pH} 7$ to determine the $\mathrm{pH}$ optima. Results showed that $\mathrm{pH}$ optima of different strains varied. While most of the fish gut isolates were effective in phytate degradation at $\mathrm{pH} 3-4$, majority of the sediment isolates did so at pH 7 (Fig. 2). The enzyme activity of the fish gut bacteria was the lowest at $\mathrm{pH} 7$. 
Identification of selected bacteria and phytase genes

The bacterial strains belonged to diverse groups, from Gram positive Bacillus to Gram negative Klebsiella, distributed among Alphaproteobacteria, Gammaproteobacteria, Actinobacteria and Firmicutes. The identified PMB were Bacillus megaterium from wetland sediments and Arthrobacter sp., Klebsiella oxytoca, Methylobacterium gregans, and Fictibacillus sp. from fish gut (Table 1, Fig. 3).

Phytate often forms complexes with other soil components that reduce its accessibility to enzyme hydrolysis (Lung and Lim 2006). However, phytate in wetlands shows relatively higher solubility and degradability (Lim et al. 2007). Suzumura and Kamatani (1995) observed complete hydrolysis of IP in 40 days period under anaerobic condition and partial hydrolysis in aerobic conditions in simulated marine sediments with potential to fortify the overlying water with $\mathrm{P}$ for primary producers. Although the exact mechanism of higher oxidation of phytate in marine environments remains unclear, reducing environments typical of wetland soils favour iron dissolution and may cause enhanced solubility of metal-bound-phytate for microbial hydrolysis (Turner et al. 2002). In a study of 28 freshwater wetlands of varied climatic, hydrogeomorphic and vegetation types Chessman et al. (2014) concluded that IP6 level in sediment is a result of biogeochemical conditions including $\mathrm{Fe}$ or $\mathrm{Al}$ oxides and redox state of the ecosystem that govern its stabilization and turnover. Thus, organic $\mathrm{P}$ present in sediment is amenable to hydrolysis by microbial processes. The present study showed presence of phytate mineralizing bacteria suggesting that many microbes were capable of utilizing phytate as a nutrient source in aquatic environments. More number of bacteria, which also showed higher phytate mineralization activity, was isolated from fish gut and sediment probably due to higher substrate availability in these niches, as compared to those from water.

Out of 137 phytate degrading colonies primarily selected, 25 were studied further based on their detectable phytate degradation on culture plates. Although 25 strains theoretically represent only a small proportion of huge microbiota in wetlands ecosystems, identification revealed that the strains belonged to various distantly related genera (Fig. 3) and might represent major taxonomic classes of phytate degrading bacteria present in the studied wetland ecosystems.

Among the isolates, sediment bacteria had an average phytase activity of $0.398 \pm 0.164 \mathrm{U}$, with insignificantly higher activity of the isolates from Akaipur than those from Bhomra for undefined reasons. Bacillus megaterium was identified as an important sediment bacterium with phytase activity 1.04-1.43U, which was higher than those of intestinal isolates. Aquatic bacteria have been found to produce phytase earlier, however, since its $\mathrm{pH}$ optima were $\mathrm{pH} 2.5$ and 5.0 it was doubted whether the enzyme would be significant in phytate turnover in natural waters having slightly acidic or alkaline $\mathrm{pH}$ (Klotz 1991). Unlike the fish gut bacteria having optimum phytase activity at low pH, pH optima of sediment bacterium Bacillus megaterium in present study, were $\mathrm{pH} 5$ and $\mathrm{pH} 7$. Yoon et al. (1994) and Demirkan et al. (2014) had also observed neutral to alkaline $\mathrm{pH}$ optima for soil Bacillus strains. The sediment pH 5.89 \pm 0.03 in Akaipur and 7.43 \pm 0.04 in Bhomra wetlands were within the favorable ranges for phytase activity of Bacillus, implying that the bacterium might play significant roles in $\mathrm{P}$ cycling in floodplain wetlands with near neutral $\mathrm{pH}$, high total organic carbon and total $\mathrm{P}$ contents. $\mathrm{P}$ is an essential element determining trophic state of aquatic ecosystems. Microbial degradation of sediment InP might thus enhance available $P$ levels for uptake by algae.

Bacillus as a promising phytase producer in aquatic system was also evident in the work of Das and Ghosh (2013), who reported an activity of $2.31 \mathrm{U}$ in Bacillus subtilis isolated from $C$. mrigala gut. In our study, unlike water and sediment isolates which showed wide range of phytase activity from $0.046-1.428 \mathrm{U}$, the average activity of fish gut isolates were higher, probably due to bottom feeding nature of the fish species studied that exposed it to higher levels of detritus phytate leading to selection of high activity microbiome in gut. Among the phytate degraders from gut, Arthrobacter sp. had the highest activity. However, the phytate mineralization activities of all our isolates were low (0.07 - 1.27 U), in comparison to $1.03-2.33 \mathrm{U}$ activity of the phytate degrading bacteria described earlier from gut of cultured carps (Roy et al. 2009, Khan et al. 2011, Khan and Ghosh 2012). Presence of a diverse bacterial species with moderate phytase activity might liberate a significant amount of available $\mathrm{P}$ for fish.

The PMB having prominent activity were identified to a number of Gram positive and Gram-negative genera and species, with Bacillus megaterium as the prevalent bacterium in freshwater sediment. Earlier studies identified Bacillus licheniformis, B. atrophaeus and B. subtilis as major phytase producers in gut of freshwater fish species like Labeo rohita, Gudusia chapra and $L$. bata (Roy et al. 2009, Khan and Ghosh 2012). Askarian et al. (2012) isolated Bacillus subtilis, Bacillus thuringiensis, Bacillus cereus and other Bacillus sp. from gastro-intestinal tract of Atlantic salmon. However, in 
Phytate mineralizing bacteria and their phytase activity from different matrices...

this study, PMB from gut of detrivorous fish C. mrigala were identified as Arthrobacter sp., Klebsiella oxytoca, Methylobacterium gregans and Fictibacillus sp. Several other workers also reported such niche specific bacterial distribution. Rhodococcus sp. was isolated from Labeo catla by Khan et al. (2011). Phytase producing Bacillus subtilis, Acinetobacter sp., Bacillus thuringiensis, Bacillus cereus, Bacillus sp. and Brochothrix sp. have been isolated from Atlantic salmon, Salmo salar and Atlantic cod (Askarian et al. 2012) and we hypothesize this as fish species-specific and niche-specific differences in distribution of different phytate degrading microbiota in the aquatic environment. Occurrence and higher activity of Bacillus megaterium in sediment in this study and other Bacillus species in fish gut in earlier studies suggest that members of the genus Bacillus might have potential applications in phytate degradation in aquaculture. Bacillus licheniformis, Bacillus subtilis and Bacillus megaterium are widely used in aquaculture in the form of water probiotics, and this study suggests that they might contribute significantly to sediment phytate degradation and $\mathrm{P}$ release. Klebsiella oxytoca (Jareonkitmongkol et al. 1997) and Arthrobacter bergei have been shown to have phytate mineralization property earlier (Hill et al. 2007). The UniProt database (http:// www.uniprot.org) also revealed presence of phytase gene in Arthrobacter sp. SJCon (Vikram et al. 2013). The phytate degrading strain PhIn4 closely matched with Methylobacterium gregans, a well-known P solubilizer (Jayashree et al. 2011, Agafonova et al. 2013); UniPort database of complete genome sequence of two Methylobacterium spp. [Methylobacterium sp. (strain 446), GenBank accession no. NC010511; Methylobacterium radiotolerans strain JCM 2831, GenBank accession no. NC010505] (Marx et al. 2012) revealed presence of phytase genes in these bacteria. Strain PhIn5 displayed 100\% similarity with Fictibacillus nanhaiensis strain JSM 082006 and Fictibacillus phosphorivorans strain Ca7, and low similarities (98\%) with both Bacillus arsenicas (Shivaji et al. 2005) and Bacillus barbaricus. However, Greengenes (http:// greengenes.lbl.gov) revealed a $100 \%$ similarity only with Bacillus sp. str. JSM 082006, and both Greengenes and RDP did not show the presence of any genus named Fictibacillus. Bacillus sp. str. JSM 082006 which was later identified as Bacillus nanhaiensis (Chen et al. 2011), has recently been reclassified into a new genus Fictibacillus (Glaeser et al. 2013). Thus, we identified the strain as Fictibacillus sp. The genus Fictibacillus have been detected with phytate mineralizing as well as $\mathrm{P}$ solubilizing activity (Maitra et al. 2015) possibly for the first time. Overall, Bacillus and Arthrobacter were found to be the major P solubilizers in freshwater ecosystems.

\section{CONCLUSION}

The enzyme phytase has found wide applications to enhance feed digestibility and nutrient availability in animal husbandry. However, pre-treatment of plant-based feed ingredients with phytase or its dietary supplementation in fisheries sector is limited. Use of phytate degrading bacteria for nutrient release in aquaculture systems is also very meager, largely due to scanty information on sediment phytate contents and bacteria that can degrade it. The present work has identified a substantial microbial diversity with higher phytate degrading ability of Arthrobacter sp. in fish gut and Bacillus megaterium in floodplain wetlands sediments. Close relationships between optimum $\mathrm{pH}$ of phytase enzyme activity and $\mathrm{pH}$ of the ecosystem of the bacterial isolates suggest potential phytate degradation by the bacteria in their respective niches. Besides enhancing $\mathrm{P}$ availability in fish gut, microbial phytate mineralization might play an important role in $\mathrm{P}$ cycling and availability in these nutrient rich floodplain wetlands.

\section{ACKNOWLEDGEMENT}

The work was supported by ICAR funded AMAAS Network project on Microbial phosphorus transformations in inland open waters.

\section{REFERENCES}

Agafonova NV, Kaparullina EN, Doronina NV, Trotsenko YA (2013) Phosphate-solubilizing activity of aerobic methylobacteria. Microbiology 82(6): 864-867.

Altschul SF, Madden TL, Schäffer AA, Zhang J, Zhang Z et al. (1997) Gapped BLAST and PSI-BLAST: a new generation of protein database search programs. Nucleic Acids Res 25(17): 3389-3402.

Askarian F, Zhou Z, Olsen RE, Sperstad S, Ring $\varnothing$ E (2012) Culturable autochthonous gut bacteria in Atlantic salmon (Salmo salar L.) fed diets with or without chitin. Characterization by $16 \mathrm{~S}$ rRNA gene sequencing, ability to produce enzymes and in vitro growth inhibition of four fish pathogens. Aquaculture 326-329: 1-8.

Bairagi A, Sarkar Ghosh K, Sen SK, Ray AK (2002) Duckweed (Lemna polyrhiza) leaf meal as a source of feedstuff in formulated diets for rohu (Labeo rohita Ham.) fingerlings after fermentation with a fish intestinal bacterium. Bioresource Technol 85: 17-24. 
Bello F, Salami-Jaji JI, Sani I, Abdulhamid A, Musa Fakai F (2013) Evaluation of some anti-nutritional factors in oil-free white Sesamum indicum L. seed cake. Int J Food Nutr Safety 4: 27-33.

Chen YG, Zhang L, Zhang YQ, He JW, Klenk HP et al. (2011) Bacillus nanhaiensis sp. nov., isolated from an oyster. Int J Syst Evol Microbiol 61(4): 888-893.

Chessman AW, Turner BL, Reddy KR (2014) Forms of organic phosphorus in wetland soils. Biogeosciences 11: 66976710 .

Das P, Ghosh K (2013) Evaluation of phytase-producing ability by a fish gut bacterium, Bacillus subtilis subsp. subtilis. J Biol Sci 13(8): 691-700.

Demirkan E, Baygin E, Usta A (2014) Screening of phytate hydrolysing Bacillus sp. isolated from soil and optimization of the certain nutritional and physical parameters on the production of phytase. Turk J Biochem 39: 206-214.

Felsenstein J (1985) Confidence limits on phylogenies: an approach using the bootstrap. Evolution 39: 783-791.

Gatlin III DM, Barrows FT, Brown P, Dabrowski K, Gaylord TG et al. (2007) Expanding the utilization of sustainable plant products in aquafeeds: a review. Aquacult Res 38(6): 551-579.

Glaeser SP, Dott W, Busse HJ, Kämpfer P (2013) Fictibacillus phosphorivorans gen. nov., sp. nov. and proposal to reclassify Bacillus arsenicus, Bacillus barbaricus, Bacillus macauensis, Bacillus nanhaiensis, Bacillus rigui, Bacillus solisalsi and Bacillus gelatini in the genus Fictibacillus. Int J Syst Evol Microbiol 63(8): 2934-2944.

Greiner R, Haller E, Konietzny U, Jany KD (1997) Purification and characterization of a phytase from Klebsiella terrigena. Arch Biochem Biophys 341: 201-206.

Greiner R, Konietzny U, Jany KD (1993) Purification and characterization of two phytases from for Escherichia coli. Arch Biochem Biophys 303: 107-113.

Hill JE, Kysela D, Elimelech M (2007) Isolation and assessment of phytate-hydrolysing bacteria from the DelMarVa Peninsula. Environ Microbiol 9(12): 3100-3107.

Jareonkitmongkol S, Ohya M, Watanabe R, Takagi H, Nakamori S (1997) Partial purification of phytase from a soil isolate bacterium, Klebsiella oxytoca MO-3. J Ferment Bioengineer 83(4): 393-394.

Jayashree S, Vadivukkarasi P, Anand K, Kato Y, Seshadri S (2011) Evaluation of pink-pigmented facultative methylotrophic bacteria for phosphate solubilization. Arch Microbiol 193: 543 552.

Kerovuo J, Lauraeus M, Nurminen P, Kalkkinen N, Apajalahti J (1998) Isolation, characterization, molecular gene cloning, and sequencing of a novel phytase from Bacillus subtilis. Appl Environ Microbiol 64: 2079-2085.

Khan A, Ghosh K (2012) Characterization and identification of gut-associated phytase-producing bacteria in some freshwater fish cultured in ponds. Acta Ichthyolog Pisc 42(1): 37-45.

Khan A, Mandal S, Samanta D, Chatterjee S, Ghosh K (2011) Phytase-producing Rhodococcus sp. (MTCC 9508) from fish gut: A preliminary study. Proceed Zool Soc 64(1): 29-34.

Klotz RL (1991) Cycling of phosphatase hydrolysable phosphorus in streams. Can J Fish Aquat Sci 48: 1460-1467.

Kumar S, Stecher G, Tamura K (2016) MEGA7: Molecular evolutionary genetics analysis version 7.0 for bigger datasets. Mol Biol Evol 33: 1870-1874.

Lim BL, Yeung P, Cheng C, Hill JE (2007) Distribution and diversity of phytate-mineralizing bacteria. ISME J 1: 321-330.

Lott JNA, Ockenden I, Raboy V, Batten GD (2000) Phytic acid and phosphorus in crop seeds and fruits: A global estimate. Seed Sci Res 10: 11-33.

Lung SC, Lim BL (2006) Assimilation of phytate phosphorus by the extracellular phytase activity of tobacco (Nicotiana tabacum) is affected by the availability of soluble phytate. Plant Soil 279: 187-199.

Maitra N, Bandopadhyay C, Samanta S, Sarkar K, Sharma AP et al. (2015) Isolation, identification and efficacy of inorganic phosphate solubilizing bacteria from oxbow lakes of West Bengal, India. Geomicrobiology J 32(8): 751-758.

Marx CJ, Bringel F, Chistoserdova L, Moulin L, Haque MFU et al. (2012) Complete genome sequences of six strains of the genus Methylobacterium. J Bacteriol 194(17): 4746-4748.

Murphy J, Riley J (1962) A modified single solution method for the determination of phosphate in natural waters. Anal Chim Acta 27: 31-36.

Paraskova JV, Jørgensen C, Reitzel K, Pettersson J, Rydin E et al. (2015) Speciation of inositol phosphates in lake sediments by ion-exchange chromatography coupled with mass spectrometry, inductively coupled plasma atomic emission spectroscopy, and ${ }^{31} \mathrm{P}$ NMR spectroscopy. Anal Chem 87(5): 2672-2677. 
Phytate mineralizing bacteria and their phytase activity from different matrices...

Powar VK, Jagannathan V (1982) Purification and properties of phytate-specific phosphatase from Bacillus subtilis. J Bacteriol 151: 1102-1108.

Reitzel K, Ahlgren J, DeBrabandere H, Waldebäck M, Gogoll A et al. (2007) Degradation rates of organic phosphorus in lake sediment. Biogeochemistry 82: 15-28.

Roy T, Mondal S, Ray AK (2009) Phytase-producing bacteria in the digestive tracts of some freshwater fish. Aquacult Res 40: 344-353.

Samanta S, Debnath D, Maitra N, Banerjee M, Chowdhury AN et al. (2015) Sediment phosphorus forms and levels in two tropical floodplain wetlands. Aquat Ecosyst Health Manag 18(4): 467-474.

Serrano L, Reina M, de Verd E, Toja J, Golterman HL (2000) Determination of the sediment phosphate composition by the EDTA method of fractionation. Limnetica 19: 199-104.

Shivaji S, Suresh K, Chaturvedi P, Dube S, Sengupta S (2005) Bacillus arsenicus sp. nov., an arsenic-resistant bacterium isolated from a siderite concretion in West Bengal, India. Int $\mathrm{J}$ Syst Evol Microbiol 55: 1123-1127.

Singh P, Kumar V, Agrawal S (2014) Evaluation of phytase producing bacteria for their plant growth promoting activities. Int J Microb. doi: http://dx.doi.org/10.1155/2014/426483.

Suzumura M, Kamatani A (1995) Origin and distribution of inositol hexaphosphate in estuarine and coastal sediments. Limnol Oceanogr 40: 1254-1261.

Tamura K, Nei M (1993) Estimation of the number of nucleotide substitutions in the control region of mitochondrial DNA in humans and chimpanzees. Mol Biol Evol 10: 512-526.
Turner BL, Papházy M, Haygarth PM, McKelvie ID (2002) Inositol phosphates in the environment. Philos Trans R Soc London Ser B 357: 449-469.

Turner BL, Newman S, Newman JM (2006) Organic phosphorus sequestration in subtropical treatment wetlands. Environ Sci Technol 40: 727-733.

Turner BL, Weckström K (2009) Phytate as a novel phosphorus-specific paleo-indicator in aquatic sediments. $\mathrm{J}$ Paleolimnol 42(3): 391-400.

Vikram S, Kumar S, Vaidya B, Pinnaka AK, Raghava GPS (2013) Draft genome sequence of the 2-chloro-4-nitrophenoldegrading bacterium Arthrobacter sp. strain SJCon. Genome Announc 1(2): e00058-13.

Yanke LJ, Bae HD, Selinger LB, Cheng KJ (1998) Phytase activity of anaerobic ruminal bacteria. Microbiology 144(6): 1565-1573.

Yasothai R (2014) Chemical composition of sesame oil cakereview. Int J Sci Env 3: 827-835.

Yoon SJ, Choi YJ, Min HK, Cho KK, Kim W et al. (1996) Isolation and identification of phytase producing bacterium, Enterobacter sp. 4, and enzymatic properties of phytase enzyme. Enzyme Microb Technol 18: 449-454.

Zhang R, Wu F, He Z, Zheng J, Song B et al. (2009) Phosphorus composition in sediments from seven different trophic lakes, China: A Phosphorus-31 NMR study. J Environ Qual 38: 353-359.

Zhu Y, Wu F, He Z, Guo J, Qu X et al. (2013) Characterization of organic phosphorus in lake sediments by sequential fractionation and enzymatic hydrolysis. Environ Sci Technol 47: 7679-7687.

*Cite this article as: Manna SK, Maitra M, Bandopadhyay C, Nandi L, Samanta S (2021) Phytate mineralizing bacteria and their phytase activity from different matrices of tropical floodplain wetlands. Explor Anim Med Res 11(2): 220-228. DOI : 10.52635/eamr/11.2.220-228. 